Contents lists available at http://ejournal.uin-suska.ac.id

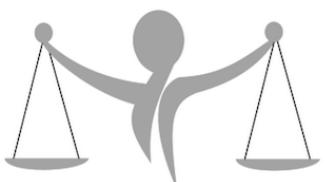

Al-Ittizaan: Jurnal Bimbingan Konseling Islam

ISSN: $2620-3820$

Journal homepage: http://ejournal.uin-suska.ac.id/index.php/alittizaan

\title{
PENGARUH MOTIVASI BELAJAR TERHADAP PRESTASI SISWA DI SEKOLAH
}

\author{
Ayudia Nur Annisa ${ }^{1}$ \\ ${ }^{1}$ Universitas Islam Negeri Sultan Syarif Kasim
}

\begin{tabular}{l} 
Article Info \\
Article history: \\
Received Jan $11^{\text {th }}, 2019$ \\
Revised Aug $20^{\text {th }}, 2019$ \\
Accepted Okt $26^{\text {th }}, 2019$ \\
\hline
\end{tabular}

Keyword:

Influence of learning motivation,

Achievement,

Student

\begin{abstract}
This study aims to find out how the influence of learning motivation on student achievement in school. This research is focused on the teacher's role in fostering student learning motivation. This motivation is very important for improving student learning achievement. Because as is well known, student motivation in learning is lacking. This will affect its success in learning. For this reason, there is a need for efforts by teachers to increase interest in learning and motivate students to be more enthusiastic about achieving in school. The approach taken in this journal research is the approach (library research) which uses literature as its object. From the research of several literatures, the results of this study indicate that learning motivation has an influence on student learning activities, especially on student achievement. The higher the student's motivation, the better the learning achievement. Vice versa, the lower the motivation of student learning, it will be difficult for these students to achieve achievement in learning. The teacher also has a very important role and has an influence on student motivation in school.
\end{abstract}

(C) 2019 The Authors. Published by UIN Sultan Syarif Kasim Riau.

This is an open access article under the CC BY license

(https://creativecommons.org/licenses/by/4.0)

\section{Corresponding Author:}

Ayudia Nur Annisa

Universitas Islam Negeri Sultan Syarif Kasim

Email: ayudia22072001@gmail.com

\section{Pendahuluan}

Pendidikan ialah hal yang amat penting dalam kehidupan kita sebagai manusia dan tentunya tidak akan dapat terpisahkan dari lingkungan keluarga, masyarakat maupun negara. Negara berkembang seperti Indonesia pastinya sangat membutuhkan kualitas yang baik terhadap sumber daya manusianya (Kusuma, 2015). Salah satu usaha untuk membentuk manusia yang memiliki kualitas dan berprestasi, maka prestasi belajar yang dimiliki oleh peserta didik haruslah baik (Joenita, 2013).

Keberhasilan belajar dipengaruhi oleh berbagai macam faktor, baik itu faktor internal maupun faktor eksternal (Nurhidayah, 2015). Faktor internal seperti faktor psikologis, faktor fisik maupun faktor kelelahan yang ada di dalam diri siswa itu sendiri. Sedangkan faktor eksternal merupakan kebalikannya yaitu faktor yang berasal dari luar seperti keluarga, 
sekolah ataupun masyarakat (Isnawati \& Setyorini, 2012). Motivasi adalah faktor yang memiliki dampak signifikan terhadap hasil belajar siswa (Nurmala, Tripalupi, \& Suharsono, 2014). Dengan adanya motivasi, maka siswa akan lebih bersungguh-sungguh, ulet, rajin dan fokus dalam belajarnya. Motivasi belajar merupakan salah satu hal yang perlu ditingkatkan dalam proses belajar di sekolah (Hamdu \& Agustina, 2011).

Fenomena yang terjadi di lapangan berkaitan dengan motivasi belajar ini ialah masih ada siswa yang terlambat masuk sekolah, ada juga siswa yang rajin masuk sekolah namun tidak ingin belajar dan hanya sekedar main-main, siswa yang masih bolos dari jam pelajaran, ada juga siswa yang sering mengantuk saat belajar di kelas dan masih banyak lagi (Kurniawan \& Wustqa, 2014). Kurangnya motivasi belajar pada siswa dikarenakan mereka kurang mampu menggunakan kekuatan dalam dirinya sendiri secara maksimal sehingga menyebabkan rendahnya prestasi belajar mereka. Pada dasarnya motivasi dalam belajar dapat membantu memahami dan menjelaskan perilaku seseorang, khususnya perilaku orang yang sedang belajar (Pratiwi, 2017).

Motivasi belajar adalah pendorong bagi siswa untuk berhasil dan berpartisipasi dalam kegiatannya dan semua itu tergantung dengan usaha dan kemampuan yang dimilikinya. Oleh sebab itu, jika siswa tersebut tidak mempunyai motivasi dalam belajar maka ia akan malas mendengarkan dan memperhatikan pelajaran yang disampaikan gurunya di depan kelas. Tidak seperti mereka yang memiliki motivasi belajar lebih tinggi, mereka akan lebih rajin dan selalu mendengarkan apa yang disampaikan gurunya selama proses belajar berlangsung (Inayah, Martono, \& Sawiji, 2013).

Maka dari itu, pemberian motivasi yang tepat akan sangat mendukung semangat belajar dan mendorong siswa untuk dapat mencapai prestasi dengan baik dan maksimal. Salah satu upaya yang dilakukan oleh guru dalam meningkatkan motivasi belajar para siswa yaitu dengan memberikan penghargaan atau hadiah kepada siswa yang berhasil mencapai prestasi yang tinggi (Mawarsih, Susilaningsih, \& Hamidi, 2013).

Penelitian ini bertujuan untuk mengetahui bagaimana pengaruh motivasi terhadap prestasi belajar siswa di sekolah. Agar dapat mencapai prestasi belajar yang baik maka sudah seharusnya seorang siswa memiliki motivasi yang tinggi dalam belajarnya.

\section{Metode Penelitian}

Penelitian ini menggunakan pendekatan tinjauan pustaka (library research) yang bersumber dari jurnal mengenai pengaruh motivasi belajar terhadap prestasi siswa di sekolah. Referensi menjadi sumber utama dalam penulisan jurnal ini. Penulis telah mengumpulkan jurnal-jurnal yang berhubungan dengan topik pembahasan kemudian membuat literature review dari masing-masing jurnal tersebut.

\section{Hasil dan Pembahasan}

Motivasi memiliki asal kata "motif" yang berarti faktor pendorong yang berasal dari dalam diri seseorang untuk melakukan kegiatan tertentu dalam mencapai suatu tujuan. Motif adalah suatu keadaan atau kecenderungan internal. Selain itu, motivasi ialah motif yang telah aktif pada waktu-waktu tertentu (Cleopatra, 2015). 
Menurut Ngalim Purwanto, motivasi adalah "dorongan"; suatu upaya yang secara sadar mempengaruhi perilaku seseorang yang telah membuatnya tergerak untuk melakukan sesuatu agar mencapai suatu tujuan (Isnawati \& Setyorini, 2012). Sedangkan menurut Mc Donald, motivasi merupakan perubahan energi yang terjadi pada seseorang ditandai dengan timbulnya perasaan dan diawali reaksi terhadap keberadaan tujuan (Haryono, 2016). Dalam psikologi motivasi didefinisikan sebagai apa yang ditemukan pada diri seseorang yang dapat mempengaruhi perilakunya (Joenita, 2013). Berdasarkan beberapa pengertian motivasi yang telah disebutkan maka dapat diambil kesimpulan bahwa motivasi merupakan pendorong yang menyebabkan munculnya suatu tindakan untuk mencapai tujuan tertentu (Mulyaningsih, 2014).

Menurut Aritonang, (2008) ada beberapa faktor yang dapat mempengaruhi prestasi belajar siswa, yaitu faktor internal, faktor eksternal dan faktor struktur pembelajaran. Faktor yang paling mempengaruhi prestasi belajar siswa ialah faktor internal berupa motivasi dan minat belajar dari dalam diri siswa tersebut.

Berikut beberapa jenis motivasi belajar menurut Nurhidayah, (2015) terbagi menjadi dua, antara lain:

1. Motivasi instrinsik, yaitu motivasi untuk menjadi aktif dan berfungsi serta tidak membutuhkan rangsangan dari luar karena sudah ada dorongan untuk melakukan suatu hal dari dalam diri sendiri. Contohnya seperti siswa yang memiliki hobi membaca maka tidak perlu diperintah dulu karena sudah pasti ia akan melakukannya sendiri dengan senang hati.

2. Motivasi ekstrinsik, yaitu motivasi untuk aktif karena adanya pengaruh faktor eksternal. Contohnya seperti seorang siswa akan belajar karena ia tahu bahwa akan ada ujian esok harinya dan mengharapkan nilai bagus ataupun mengharapkan hadiah semata.

Ciri-ciri siswa yang memiliki motivasi menurut Mulyaningsih, (2014) antara lain:

1. Siswa lebih percaya diri dalam mengerjakan tugas yang berkaitan dengan prestasi belajarnya.

2. Siswa berwawasan ke depan dan lebih mampu menghentikan kepuasan untuk menerima reward di masa depan.

3. Siswa cenderung memilih tugas yang memiliki tingkat kesulitan lebih dari biasanya.

4. Siswa tidak suka membuang-buang waktu untuk hal yang tidak begitu penting.

5. Siswa menjadi lebih kuat dan mampu dalam menghadapi tugasnya.

Guru memiliki peran yang sangat penting dalam upaya untuk meningkatkan motivasi belajar terhadap prestasi para siswa. Menurut Suprihatin, (2015) ada berbagai macam hal yang diperlukan oleh guru dalam meningkatkan motivasi belajar siswa dengan beberapa cara berikut:

1. Guru sebaiknya memperjelas tujuan yang akan dicapai

Tujuan yang jelas memungkinkan siswa untuk memahami arah keinginan siswa itu sendiri. Pemahaman siswa tentang tujuan dalam belajar dapat meningkatkan minat siswa 
dalam proses pembelajaran yang pada akhirnya akan menumbuhkan motivasi belajar siswa. Semakin jelas tujuannya, semakin kuat pula motivasi siswa untuk belajar.

2. Guru dapat menumbuhkan motivasi belajar pada siswa

Siswa akan termotivasi dalam belajar apabila mereka mempunyai minat untuk belajar. Oleh sebab itu, menumbuhkan minat siswa dalam belajar adalah salah satu cara untuk menumbuhkan motivasi belajar pada diri siswa itu sendiri. Salah satu caranya yaitu dengan menghubungkan pengalaman belajar siswa tersebut dengan minat yang dimiliki siswa.

3. Guru dapat menciptakan suasana belajar yang menyenangkan untuk siswa

Hanya dalam suasana yang menyenangkan, aman dan tanpa rasa takutlah siswa dapat belajar dengan baik. Usahakan agar kelas tetap hidup, segar dan bebas dari stress. Karena itu guru sesekali dapat melakukan sesuatu yang menarik.

4. Guru menyampaikan materi pembelajaran dengan metode yang menarik

Guru harus mampu menyampaikan materi pembelajaran dengan cara yang menarik untuk siswanya. Materi yang disampaikan dengan teknik yang baru dan dikemas dengan baik dan dapat didukung oleh media atau alat yang belum diketahui oleh siswa sehingga menarik minat mereka dalam belajar. Melalui pembelajaran yang menarik tentu akan meningkatkan rasa ingin tahu siswa dalam belajar sehingga akan memotivasi siswa dalam kegiatan belajar.

5. Sebaiknya guru memberikan pujian yang sesuai dengan keberhasilan setiap siswa

Ketika siswa merasa dihargai maka motivasi akan tumbuh dengan sendirinya. Dalam belajar, pujian digunakan sebagai salah satu cara untuk memotivasi siswa. Karena peserta didik juga manusia tentulah mereka akan merasa senang ketika dipuji oleh gurunya. Akan tetapi pujian yang disampaikan harus menyesuaikan dengan hasil belajar siswa tersebut. Jangan berlebihan dalam memuji karena terkesan tidak natural. Pujian yang baik itu ialah pujian yang secara alami muncul dari hati guru dengan tujuan untuk menghargai usaha yang telah mereka lakukan dalam belajar.

\section{Kesimpulan}

Motivasi belajar merupakan dorongan yang terdapat dalam diri seorang siswa untuk mencapai tujuan pembelajaran. Dengan adanya motivasi, siswa akan memiliki semangat yang tinggi untuk mencapai prestasi belajar yang baik. Siswa yang memiliki motivasi belajar yang tinggi maka ia akan bersungguh-sungguh dalam mendengarkan dan menerima pelajaran yang diberikan oleh guru di kelas. Peran guru juga sangat mempengaruhi motivasi belajar siswa, maka dari itu guru harus bisa menyesuaikan dirinya dengan siswa agar mereka mendapatkan kenyamanan dan suasana belajar yang menyenangkan. 


\section{Daftar Pustaka}

Aritonang, K. T. (2008). Minat dan Motivasi dalam Meningkatkan Hasil Belajar Siswa. Jurnal Pendidikan Penabur, 115(10), 11-21.

Cleopatra, M. (2015). Pengaruh Gaya Hidup dan Motivasi Belajar terhadap Prestasi Belajar Matematika. Formatif: Jurnal Ilmiah Pendidikan MIPA, 5(2), 168-181. https://doi.org/http://dx.doi.org/10.30998/formatif.v5i2.336

Hamdu, G., \& Agustina, L. (2011). PENGARUH MOTIVASI BELAJAR SISWA TERHADAP PESTASI BELAJAR IPA DI SEKOLAH DASAR (Studi Kasus terhadap Siswa Kelas IV SDN Tarumanagara Kecamatan Tawang Kota Tasikmalaya). Jurnal Penelitian Pendidikan, 12(1), 81-86.

Haryono, S. (2016). Pengaruh Kedisiplinan Siswa Dan Motivasi Belajar Terhadap Prestasi Belajar Siswa Pada Mata Pelajaran Ekonomi. Jurnal Ilmiah Kependidikan, 3(3), 261-274.

Inayah, R., Martono, T., \& Sawiji, H. (2013). PENGARUH KOMPETENSI GURU, MOTIVASI BELAJAR SISWA, DAN FASILITAS BELAJAR TERHADAP PRESTASI BELAJAR MATA PELAJARAN EKONOMI PADA SISWA KELAS XI IPS SMA NEGERI 1 LASEM. Jurnal Pendidikan Insan Mandiri, 1(1), 1-12.

Isnawati, N., \& Setyorini, D. (2012). Pengaruh Perhatian Orang Tua Dan Motivasi Belajar Siswa Terhadap Prestasi Belajar Akuntansi Pada Kompetensi Mengelola Dokumen Transaksi Siswa Kelas X Program Keahlian Akuntansi Smk Cokroaminoto 1 Banjarnegara Tahun Ajaran 2011/2012. Jumal Pendidikan Akuntansi Indonesia, 10(1), 2747. https://doi.org/https://doi.org/10.21831/jpai.v10i1.920

Joenita, D. (2013). Pengaruh Motivasi Belajar dan Gaya Belajar terhadap Prestasi Belajar Ekonomi Siswa SMA Negeri di Kota Tuban. Jurnal Ekonomi Pendidikan Dan Kewirausahaan, $1(1)$, 79-90. https://doi.org/http://dx.doi.org/10.26740/jepk.v1n1.p79-90

Kurniawan, D., \& Wustqa, D. U. (2014). Pengaruh Perhatian Orangtua, Motivasi Belajar, Dan Lingkungan Sosial Terhadap Prestasi Belajar Matematika Siswa Smp. Jurnal Riset Pendidikan Matematika, 1(2),

176-187. https://doi.org/https://doi.org/10.21831/jrpm.v1i2.2674

Kusuma, Z. L. (2015). PENGARUH MOTIVASI BELAJAR DAN KEDISIPLINAN BELAJAR TERHADAP PRESTASI BELAJAR MATA PELAJARAN AKUNTANSI SISWA KELAS XI IPS SMA N 3 PATI TAHUN PELAJARAN 2013/2014. Economic Education Anallysis Journal, 4(1), 164-171. https://doi.org/http://dx.doi.org/10.24269/dpp.v3i2.83

Mawarsih, S. E., Susilaningsih, \& Hamidi, N. (2013). Pengaruh Perhatian Orang Tua dan Motivasi Belajar Terhadap Prestasi Belajar Siswa SMA Negeri Jumapolo. Jupe Uns, 1(3), 1-13. https://doi.org/https://doi.org/10.21831/jpai.v10i1.920

Mulyaningsih, I. E. (2014). Pengaruh Interaksi Sosial Keluarga, Motivasi Belajar, dan Kemandirian Belajar terhadap Prestasi Belajar. Jurnal Pendidikan Dan Kebudayaan, 20(4), 441. https://doi.org/10.24832/jpnk.v20i4.156

Nurhidayah, D. A. (2015). Pengaruh Motivasi Berprestasi dan Gaya Belajar Terhadap Prestasi Belajar Siswa Pada Mata Pelajaran Matematika SMP. Jurnal Dimensi Pendidikan Dan Pembelajaran, 3(2),

$13-24$.

https://doi.org/http://dx.doi.org/10.24269/dpp.v3i2.83

Nurmala, D. A., Tripalupi, L. E., \& Suharsono, N. (2014). Pengaruh Motivasi Belajar Dan Aktivitas Belajar Terhadap Hasil Belajar Akuntansi. Jurnal Pendidikan Ekonomi, 4(1), 8695.

Pratiwi, S. S. (2017). Pengaruh Keaktifan Mahasiswa Dalam Organisasi Dan Motivasi 
Belajar Terhadap Prestasi Belajar Mahasiswa Fakultas Ekonomi Universitas Negeri Yogyakarta. Jurnal Pendidikan Dan Ekonomi, 6(1), 54-64.

Suprihatin, S. (2015). Upaya Guru Dalam Meningkatkan Motivasi Belajar Siswa. PROMOSI (Jurnal Pendidikan Ekonomi),

https://doi.org/http://dx.doi.org/10.24127/ja.v3i1.144

73-82. 